\title{
The Impact of Motivation on The Performance of Employees in Hotel Sapadia Pematangsiantar
}

\author{
Marto Silalahi ${ }^{1^{*}}$, Sudung Simatupang ${ }^{2}$, Yosi Anindhita Molek Manalu ${ }^{3}$ \\ ${ }^{1}$ Sekolah Tinggi IImu Manajemen, Pematangsiantar 21118, Indonesia \\ ${ }^{2}$ Sekolah Tinggi IImu Manajemen, Pematangsiantar 21118, Indonesia \\ ${ }^{3}$ Sekolah Tinggi Ilmu Manajemen, Pematangsiantar 21118, Indonesia \\ Email:martosilalahi70@gmail.com, selitaefraim@gmail.com,yosimolek18@gmail.com
}

ARTICLE INFO.

Date received : 27

November 2020

Revision date : 19

December 2020

Date received : 10

January 2021

\section{Keywords: \\ Motivation \\ The Performance of \\ Employees}

\begin{abstract}
The concept of this study aims to examine the effect of motivation on the performance of employees of Hotel Sapadia Pematangsiantar, amounting to 42 people with research time in April 2020. The study was conducted with qualitative and quantitative analysis. The results of the validity test show that the calculated $r$ value is greater than critical $r$ with the results of the research variable being declared valid, the reliability test shows that all research variables are declared reliable. Then, the determination coefficient test shows that the $R$ value has a strong and positive relationship with motivation and employee performance and motivation variable is able to explain and measure employee work variable. The results of the normality test explain that the research is normally distributed. The simple equation regression equation shows positive results of motivation on employee performance and the hypothesis test accepts the hypothesis of the study.
\end{abstract}

Coresponden Author:

Email: martosilalahi70@gmail.com Article with open access under license

\section{INTRODUCTION}

The development of the potential of an The performance of the company becomes the accumulated performance of each organizational unit as well as the performance of all individuals, from operations to management. The success of an organizational life cannot be separated from the influence of performance. According to Rosdanita in (Simatupang \& Efendi, 2020) that performance is the level of achievement of tasks carried out in a program of activities and policies in realizing the goals, mission objectives and mission of the company. To be able to create high performance, it is necessary to increase optimal performance and make a positive contribution to organizational development (Indrawati, 2016). Performance can be a description of a job that is systematically related to the strengths and weaknesses of an individual or group (Cascio, 2012). There are three measuring tools used to measure employee performance: 1) Traits such as pleasant personality, initiative, creativity, warmth and then aggressive nature; 2) Behavior that shows employees in providing suggestions or ideas and is able to maintain organizational confidentiality; 3) Results given on sales and production results, errors during work and quality of work production (Sudiarditha, 2011)

organization's workforce becomes a measurement model for the success of the organization or company. Employees become the pillars who are directly involved in managing the interests of the organization. Human resources are an important factor in achieving organizational goals so that organizations or institutions have the potential of a competent workforce in carrying out the tasks assigned to them by the organization (Ambarita et al., 2020) including hotel organizations.

The hotel business is a form of accommodation provision in the form of rooms in a building equipped with services such as food, drinks, and entertainment on a daily basis in order to achieve goals (Peraturan Menteri Pariwisata Dan Ekonomi Kreatif Republik Indonesia Nomor PM.53/HM.001/MPEK: Tentang Standar Usaha Hotel, 2013), then hotels also carry out other services or facilities by collecting payments (Peraturan Pemerintah Republik Indonesia Nomor 65 Tahun Tentang Pajak Daerah, 2001) in other words, accommodation also needs to be managed commercially (Widanaputra et al., 2009). To make the hotel grow and develop, good performance is needed because this performance does not only grow for companies engaged in the product industry but also for companies engaged in the service industry, in this case, the hotel services business. Employee performance can be influenced by several factors due to interaction, one of which is motivation (Robbins \& Judge, 2017)). Chung and Meggison in (Prabu \& Wijayanti, 2016) explained that motivation can be a formula for target behavior. 
Motivation can lead to intensity, direction, and continuous efforts from individuals to achieve goals (Wibowo, 2018). Motivation is important to increase work effectiveness because with high work motivation trying to complete the work as much as possible (Rizvitasari et al., 2002). 

Motivation is always aimed at managing human resources in general and subordinates in particular (Purnama, 2008), research from (Muliharta, 2015), (Arianindita, 2018) that there is an effect of motivation on performance. Motivation at Sapadia Hotel Pematangsiantar lies in social needs, it can be seen from the friendship and communication relations that exist between fellow employees that are still not good. For selfactualization needs,

it can be seen from employees who have the potential but do not want to develop their knowledge in their field of work due to the absence of a clear career path.

Seeing the explanation above, the formulation of the problem: "how is the impact of motivation on the employee performance of Hotel Sapadia Pematangsiantar?"

\section{METODE}

This research was conducted to examine the impact of motivation on employee performance (Kristanto \& Nondolesmono, 2017). The concept of this research uses qualitative and quantitative analysis, the research location is PT. Sapadia Hotel Pematangsiantar with 42 employees studied during April 2020. The results of the analysis were carried out by testing the validity, reliability, coefficient of determination, normality test, simple regression equation test and t hypothesis test. Data testing was carried out with the help of SPSS.

\section{RESULTS AND DISCUSSION Respondents' description. \\ Table 1}

Respondents' description

\begin{tabular}{|c|c|c|c|}
\hline $\begin{array}{l}\text { Respondents' } \\
\text { Data }\end{array}$ & $\begin{array}{c}\text { Respondents' } \\
\text { Description }\end{array}$ & Total & Percentage \\
\hline \multirow{2}{*}{ Sex } & Male & 32 & $76,19 \%$ \\
\hline & Female & 10 & $23,81 \%$ \\
\hline \multirow{4}{*}{$\begin{array}{l}\text { Respondents' } \\
\text { Age }\end{array}$} & $21-30$ & 26 & $61,90 \%$ \\
\hline & $31-40$ & 14 & $33,33 \%$ \\
\hline & $41-50$ & 2 & $4,77 \%$ \\
\hline & $51-60$ & 0 & $0 \%$ \\
\hline \multirow{3}{*}{$\begin{array}{l}\text { Respondents' } \\
\text { Education }\end{array}$} & High School & 31 & $73,81 \%$ \\
\hline & Diploma & 6 & $14,29 \%$ \\
\hline & $\begin{array}{l}\text { Bachelor's } \\
\text { Degree }\end{array}$ & 5 & $11,90 \%$ \\
\hline \multirow{4}{*}{$\begin{array}{c}\text { Employees' } \\
\text { Working Period }\end{array}$} & $<1$ year & 3 & $7,14 \%$ \\
\hline & $2-5$ years & 37 & $88,09 \%$ \\
\hline & $6-10$ years & 2 & $4,77 \%$ \\
\hline & $>11$ years & 0 & $0 \%$ \\
\hline
\end{tabular}

Table 1 shows the results of 32 people (76.19\%) male employees while 10 people $(23.81 \%)$ are female employees, because men's work is more needed in jobs in hotels such as lifting guests' luggage and tidying up rooms. For ages 21-30 years there are 26 people (61.90\%), ages $31-40$ years are 14 people (33.33\%), then ages $41-50$ years are 2 people $(4.77 \%)$. If you look at the ages of the respondents, the most of the respondents are 21-30 years old, this is because employees aged 21-30 years are more productive at work. Those with a service period of $<1$ year totaling 3 people $(7.14 \%)$, 37 employees with a 2-5 year working period $(88.09 \%)$, then 2 employees with a working period of $6-10$ years $(4.77 \%)$, then there are no employees with a working period of $>11$ years. This is because the hotel has not been in operation for a long time, so the average working period of its employees is under 5 years. There are 31 employees with high school education (73.81\%), 6 employees with Diploma education (14.29\%), 5 employees with a bachelor's degree (11.90\%), most of the employees at Sapadia Hotel have high school education. Because the minimum requirement to work at Sapadia Hotel Pematangsiantar is high school education and equivalent

Validity test.

Table 2

Validity test

\begin{tabular}{llcl}
\hline \multirow{2}{*}{ Variables } & \multicolumn{1}{c}{$\begin{array}{c}\text { Variable } \\
\text { Indicators }\end{array}$} & $\begin{array}{c}\text { Results of } \\
\text { r Count }\end{array}$ & Results \\
\hline \multirow{5}{*}{ Motivation } & $\begin{array}{l}\text { Physiological } \\
\text { needs }\end{array}$ & 0,917 & Valid \\
\cline { 2 - 4 } & Safety needs & 0,920 & Valid \\
\cline { 2 - 4 } & Social needs & 0,875 & Valid \\
\cline { 2 - 4 } & Esteem needs & 0,887 & Valid \\
\cline { 2 - 4 } & $\begin{array}{l}\text { Self- } \\
\text { actualization } \\
\text { needs }\end{array}$ & 0,829 & Valid \\
\hline \multirow{5}{*}{ Employee } & Quantity & 0,523 & Valid \\
\cline { 2 - 4 } performance & Quality & 0,579 & Valid \\
\cline { 2 - 4 } & Punctuality & 0,576 & Valid \\
\cline { 2 - 4 } & Presence & 0,618 & Valid \\
\cline { 2 - 4 } & $\begin{array}{l}\text { Ability to work } \\
\text { together }\end{array}$ & 0,573 & Valid \\
\hline & Source: Data prosecing,2020 & \\
\hline
\end{tabular}

The validity test shown in table 2 shows the results that all research variables and their indicators are declared valid because all results are above the critical $r 0.3$ and the conclusion is that the data from the study are declared valid.

\section{Reliability test}

Table 3

Reliability test

\begin{tabular}{|c|c|c|c|}
\hline Variables & $\begin{array}{l}\text { Variable } \\
\text { Indicators }\end{array}$ & $\begin{array}{c}\text { Results of } \\
\text { r Count }\end{array}$ & Results \\
\hline \multirow{5}{*}{ Motivation } & $\begin{array}{l}\text { Physiological } \\
\text { needs }\end{array}$ & 0,981 & Reliable \\
\hline & Safety needs & 0,928 & Reliable \\
\hline & Social needs & 0,982 & Reliable \\
\hline & Esteem needs & 0,982 & Reliable \\
\hline & $\begin{array}{l}\text { Self- } \\
\text { actualization } \\
\text { needs }\end{array}$ & 0,983 & Reliable \\
\hline \multirow{5}{*}{$\begin{array}{l}\text { Employee } \\
\text { performance }\end{array}$} & Quantity & 0,887 & Reliable \\
\hline & Quality & 0,884 & Reliable \\
\hline & Punctuality & 0,885 & Reliable \\
\hline & Presence & 0,883 & Reliable \\
\hline & $\begin{array}{l}\text { Ability to work } \\
\text { together }\end{array}$ & 0,885 & Reliable \\
\hline
\end{tabular}

The results from table 3 for the reliability test, all the indicators of Cronbach's Alpha If Item Deleted 
variable are greater than 0.70 . These results mean that all indicators of the study are declared reliable

\section{Coefficient of Determination}

The coefficient of determination is used to measure the ability of the independent variable (motivation) to explain the dependent variable (employee performance).

Table 4

Coefficient of determination.

\begin{tabular}{lcccc}
\hline Model & $\mathrm{R}$ & $\mathrm{R}$ Square & $\begin{array}{l}\text { Adjusted R } \\
\text { Square }\end{array}$ & $\begin{array}{l}\text { Std. Error of } \\
\text { the Estimate }\end{array}$ \\
\hline 1 &, $776^{\mathrm{a}}$ &, 602 &, 592 & 5,488 \\
\hline a. Predictors: (Constant), Motivation & \\
\hline b. Dependent Variable: Employee Performance \\
Source: Data prosecing,2020
\end{tabular}

The conclusion from the results of table 4 is that the correlation value of $R=0.776$, which means that there is a strong and positive relationship between motivation and employee performance, the coefficient of determination to measure the ability of motivation to explain employee performance is $60.2 \%$ while the remaining $39.8 \%$ can be explained by other predictors not discussed in this study, such as work environment, work culture, intellectual ability, work discipline and other variables that can affect employee performance.

\section{Normality Test}

Table 5

Normality Test One-Sample Kolmogorov-Smirnov Test

\begin{tabular}{llrr}
\hline & & & \multicolumn{2}{c}{$\begin{array}{c}\text { Employee } \\
\text { Performance }\end{array}$} \\
\hline $\mathrm{N}$ & & 42 & 42 \\
\hline \multirow{2}{*}{$\begin{array}{l}\text { Normal } \\
\text { Parameters }\end{array}$} & Mean & 56,52 & 59,55 \\
\cline { 2 - 4 } & $\begin{array}{l}\text { Std. } \\
\text { Deviation }\end{array}$ & 17,536 & 8,594 \\
\hline Most Extreme & Absolute &, 177 &, 097 \\
\cline { 2 - 4 } Differences & Positive &, 146 &, 097 \\
\cline { 2 - 4 } & Negative &,- 177 &, 079 \\
\hline Kolmogorov-Smirnov Z & 1,149 &, 628 \\
\hline \multicolumn{2}{c}{ Asymp. Sig. (2-tailed) } &, 143 &, 826 \\
\hline \multicolumn{2}{l}{} & Source: Data prosecing,2020
\end{tabular}

Table 5 explains that the normality test shows the asymp. sig. (2-tailed) results for the motivation variable is 0.143 and the employee performance is 0.026 , the value is above sig 0.05 , meaning that in this study, the variables of motivation and employee performance are normally distributed.

\section{Simple regression equation test.}

The simple regression equation is used to examine the influence of motivation variables on employee performance variables. These results can be seen in table 6 below:
Table 6

Simple regression equation test

\begin{tabular}{|c|c|c|c|c|}
\hline \multirow{2}{*}{\multicolumn{2}{|c|}{ Model }} & \multicolumn{2}{|c|}{$\begin{array}{l}\text { Unstandardized } \\
\text { Coefficients }\end{array}$} & \multirow{2}{*}{$\begin{array}{c}\begin{array}{c}\text { Standardized } \\
\text { Coefficients }\end{array} \\
\text { Beta }\end{array}$} \\
\hline & & $\mathrm{B}$ & Std. Error & \\
\hline \multirow[t]{2}{*}{1} & (Constant) & 38,052 & 2,890 & \\
\hline & Motivation & ,380 & ,049 & ,776 \\
\hline
\end{tabular}

Table 6 of the simple regression test produces the equation $Y=38.052+0,380$ which explains that if the constant value is 38.052 , then the concept means that if the motivation variable is considered zero (0) then the result of employee performance is 38.052. Furthermore, if the coefficient value of the direction of motivation is 0.380 , which means that when the motivation value increases by 1 (one) unit, the employee performance value $(\mathrm{Y})$ can change with a value of 0.380 unit, with the other assumptions that it is fixed. Motivation has a positive impact on employee performance (Zameer et al., 2014)

\section{Hypothesis testing}

Hypothesis testing from this study was conducted to determine whether or not the answers to the research results were found. The hypothesis test results can be seen in table 7 below

Table 7

t hypothesis testing

\begin{tabular}{lrrr} 
Model & \multicolumn{2}{c}{$\mathrm{t}$} & \multicolumn{2}{c}{ Sig. } \\
\hline 1 & (Constant) & 13,168 &, 000 \\
\cline { 2 - 4 } & Motivation & 7,780 &, 000 \\
\hline \multicolumn{2}{c}{ Source: Data prosecing,2020 }
\end{tabular}

For the hypothesis answer in table 7 , seen on the results of the tcount table value with a value of 10.898 for the emotional intelligence variable $>$ with the results of t table $d f=n-k(42-2)=2.021$ and the significance level in the table is 0.000 .

The criteria of the answer

1. Based on the significance value (sig) in the table of $0.000<$ probability of 0.005 , then there is an influence of the motivation variable on employee performance.

2. Based on the $t$ value with a value of $7,780>$ from $t$ table 2,021 the result is there is motivation towards employee performance.

\section{The influence of motivation on employee performance.}

The results of the analysis test carried out in this study find that there is an influence of motivation on employee performance, this is in line with research from (Mustapha, 2020); (Zameer et al., 2014); (Tondok, 2017) but the research from (Luhur, 2014); (Dhermawan et al., 2012) that motivation has no effect on performance and even 
has a negative effect on performance (Julianry et al., 2017).

\section{CONCLUSION}

The results of the study found that motivation has a positive influence on employee performance as indicated by the results of the simple regression equation test and the thypothesis test. Motivation is the most important part of employee performance, without motivation it can result in decreased performance.

\section{REFERENCES}

Ambarita, M. H., Simatupang, S., \& Candra, V. (2020). Efek Mediasi Motivasi Atas Hubungan Etos Kerja Terhadap Kinerja Pegawai Dinas Kehutanan UPT. Kesatuan Pengelolaan Hutan Wilayah II Pematangsiantar. Jesya (Jurnal Ekonomi \& Ekonomi Syariah), 3(2), 168-178. https://doi.org/10.36778/jesya.v3i2.196

Arianindita, T. D. (2018). Pengaruh Motivasi Kerja, Disiplin Kerja dan Lingkungan Kerja Terhadap Kinerja Karyawan Hotel Grand Sae di Surakarta. Kelola: Journal Business Dan Management, 5(2), 22-27.

Cascio, W. (2012). Mqnaging Human Resources Productivity, Quality of Work Life, Profits. (9th Editio). McGraw Hill.

Dhermawan, A. A. N. B., Sudibya, I. G. A., \& Utama, I. W. M. (2012). Pengaruh Motivasi, Lingkungan Kerja, Kompetensi, Dan Kompensasi Terhadap Kepuasan Kerja Dan Kinerja Pegawai Di Lingkungan Kantor Dinas Pekerjaan Umum Provinsi Bali. Jurnal Manajemen, Strategi Bisnis, Dan Kewirausahaan, 6(2), 173-184.

Indrawati, I. A. A. N. (2016). Pengaruh Motivasi Dan Kepuasan Kerja Karyawan Terhadap Kinerja Karyawan Hotel Di Kawasan Lovina. Jurnal IImiah Hospitality Management, 7(1), 59-64.

Julianry, A., Syarief, R., \& Affandi, M. J. (2017). Pengaruh Pelatihan Dan Motivasi Terhadap KinerJa Karyawan serta KinerJa Organisasi Kementerian KomuniKasi dan Informatika. Jurnal Aplikasi Bisnis Dan Manajemen, 3(2), 236-245.

https://doi.org/10.17358/JABM.3.2.236

Kristanto, J. S., \& Nondolesmono, H. (2017). Analisa Pengaruh Motivasi Kerja dan Kompensasi terhadap Kinerja Karyawan F\&B Service Departement di Hotel X, Sawangan, Nusa Dua, Bali. Jurnal Hospitality Dan Manajemen Jasa, 5(2), 374-385.
Luhur, R. Y. (2014). Pengaruh Kepemimpinan, Motivasi Kerja Dan Lingkungan Kerja Terhadap Kinerja Karyawan Pada Biro Pengawasan Dan Pemeriksaan PT BANK PANIN TBK. Jurnal OE, VI(3), 327-344.

Muliharta, K. (2015). PENGARUH KEMAMPUAN KERJA DAN MOTIVASI KERJA TERHADAP KINERJA KARYAWAN PADA HOTEL PURI BAGUS LOVINA PADA TAHUN 2014. Jurnal Jurusan Pendidikan Ekonomi (JJPE), 5(1), 114.

Mustapha, K. S. G. (2020). The Impact of Motivation on Employee 's Performance in some Public and Private Schools in Talata Mafara. International Journal of Applied Research in Management and Economics, 3(1), 21-29.

Peraturan Menteri Pariwisata dan Ekonomi Kreatif Republik Indonesia Nomor PM.53/HM.001/MPEK: Tentang Standar Usaha Hotel, (2013).

Peraturan Pemerintah Republik Indonesia Nomor 65 Tahun Tentang Pajak Daerah, (2001).

Prabu, A. S., \& Wijayanti, D. T. (2016). Pengaruh Penghargaan dan Motivasi Terhadap Kinerja Karyawan (Studi Pada Divisi Penjualan PT. United Motors Center Suzuki Ahmad Yani, Surabaya). Jurnal Ekonomi Bisnis Dan Kewirausahaan, 5(2), 104. https://doi.org/10.26418/jebik.v5i2.17144

Purnama, R. (2008). Pengaruh Motivasi Kerja Terhadap Produktivitas Kerja Karyawan Pada Bagian Produksi Cv. Epsilon Bandung. Strategic: Jurnal Pendidikan Manajemen Bisnis, 8(2), 58. https://doi.org/10.17509/strategic.v8i2.1028

Rizvitasari, K., Rachma, N., \& Khalikussabir. (2002). Pengaruh Motivasi Kerja Dan Disiplin Kerja Terhadap Kinerja Karyawan (Varna Culture Hotel Surabaya). E - Jurnal Riset ManajemenPRODI MANAJEMEN, 9(10), 5367.

Robbins, S. P., \& Judge, T. A. (2017). Organizational Behavior (17Th Edition (ed.)). Pearson.

Simatupang, S., \& Efendi. (2020). Kecerdasan Emosional Serta Dampaknya Untuk Kinerja Pegawai Dinas Pekerjaan Umum Dan Penataan Ruang Kota Pematangsiantar. Jurnal Manajemen (Edisi Elektronik) Sekolah Pascasarjana Universitas Ibn Khaldun Bogor, 
11(2), 152-161. https://doi.org/10.32832/jmuika.

Sudiarditha, I. K. R. (2011). Kinerja Karyawan Hotel Dalam Prespektif Global. PT Bumi Timur jaya.

Tondok, F. A. P. (2017). Pengaruh Motivasi Kerja dan Kepuasan Kerja Terhadap Kinerja Karyawan Pada Hotel ljen Suites Malang. Jurnal IImiah Mahasiswa FRB, 5(2), 1-13. https://jimfeb.ub.ac.id/index.php/jimfeb/article/v iew $/ 4387 / 0$

Wibowo. (2018). Manajemen Kinerja. Raja Grafindo Persada.
Widanaputra, Bambang, H., Suprasto, Aryanto, D., \& Sari, R. (2009). Akuntansi Perhotelan: pendekatan sistem informasi. Graha IImu.

Zameer, H., Ali, S., Nisar, W., \& Amir, M. (2014). The Impact of the Motivation on the Employee ' s Perfor mance in Beverage Industry of Pakistan. International Journal of Academic Research in Accounting, Finance and Management Sciences, 4(1), 293-298. https://doi.org/10.6007/IJARAFMS/v4-i1/630 